\title{
Receptors with Different Affinities Mediate Phasic and Tonic GABA Conductances in Hippocampal Neurons
}

\author{
Brandon M. Stell and Istvan Mody \\ Interdepartmental Program in Molecular, Cellular, and Integrative Physiology and Departments of Neurology and \\ Physiology, University of California Los Angeles School of Medicine, Los Angeles, California 90095
}

\begin{abstract}
A tonic inhibitory conductance mediated by $\mathrm{GABA}_{\mathrm{A}}$ receptors that supplements the phasic inhibition produced by IPSCs has been identified in the hippocampus and cerebellum. It is presently unknown whether tonic and phasic inhibitions are mediated by $\mathrm{GABA}_{\mathrm{A}}$ receptors with different subunit assemblies. Here we demonstrate that a low concentration (200 nM) of the highly specific competitive $\mathrm{GABA}_{\mathrm{A}}$ antagonist SR95531 (gabazine) reduces phasic inhibition in hippocampal granule cells by
\end{abstract}

$71 \%$ but has no effect on tonic inhibition, whereas a high concentration $(10 \mu \mathrm{M})$ of the antagonist blocked both conductances. These findings are consistent with tonic and phasic conductances being mediated by different $\mathrm{GABA}_{\mathrm{A}}$ receptor subtypes with different affinities for GABA.

Key words: GABA affinity; tonic inhibition; phasic inhibition; competitive $\mathrm{GABA}_{A}$ antagonist; SR95531; IPSC amplitude quantification
It is now known that neurons exhibit a tonic form of GABAergic inhibition in addition to phasic inhibition mediated by inhibitory postsynaptic currents (Brickley et al., 1996, 2001; Mody, 2001; Nusser and Mody, 2002), but these two types of inhibition have not been compared to determine whether they are affected equally by competitive antagonists. If the two forms of inhibitory conductance are mediated by separate populations of $\mathrm{GABA}_{\mathrm{A}}$ receptors $\left(\mathrm{GABA}_{\mathrm{A}} \mathrm{Rs}\right)$ with different molecular assemblies, then it is likely that competitive antagonists do not block these receptors equally.

Electrophysiological (Brickley et al., 1999) and anatomical (Somogyi et al., 1996) evidence from the cerebellum and hippocampus indicate that the receptors mediating the phasic currents are found within synapses and are primarily, if not exclusively, composed of $\mathrm{GABA}_{\mathrm{A}}$ Rs containing $\gamma$-subunits that are essential for functioning inhibitory synapses (Essrich et al., 1998). The subunit composition of the receptors underlying tonic inhibition has yet to be elucidated. Because such receptors most likely perform quite a different function than those mediating IPSCs, they are likely to have a different subunit composition and a distinct subcellular localization. Unlike receptors mediating IPSCs, tonically active $\mathrm{GABA}_{\mathrm{A}} \mathrm{Rs}$ must show incomplete desensitization and be activated by the low ambient GABA concentrations found in the brain (Lerma et al., 1986; Tossman et al., 1986). A nondesensitizing receptor with high affinity for GABA located extrasynaptically would be ideal for mediating tonic currents. It is therefore possible that different kinetics and binding affinities of the different subpopulations of $\mathrm{GABA}_{\mathrm{A}} \mathrm{Rs}$ underlying tonic and phasic conductances cause them to respond differently when exposed to competitive antagonists.

The binding mechanisms of agonists and competitive antago-

\footnotetext{
Received Jan. 30, 2002; revised Feb. 27, 2002; accepted March 5, 2002.

This study was supported by National Institute of Neurological Disorders and Stroke Grant NS 30549 and the Coelho Endowment to I.M. We thank Kimmo Jensen and Tom Otis for helpful comments on this manuscript.

Correspondence should be addressed to Istvan Mody, Department of Neurology, RNRC 3-155, University of California Los Angeles School of Medicine, 710 Westwood Plaza, Los Angeles, CA 90095-1769. E-mail: mody@ucla.edu. Copyright (C) 2002 Society for Neuroscience $0270-6474 / 02 / 220001-05 \$ 15.00 / 0$
}

nists are fundamentally distinct (Jones et al., 2001) and have been shown to be unrelated for GABA and the competitive $\mathrm{GABA}_{\mathrm{A}} \mathrm{R}$ antagonist SR95531 (gabazine) on $\gamma$ - and $\delta$-subunit-containing receptors (Wafford et al., 2001). Receptors containing either of these two mutually exclusive subunits (Araujo et al., 1998) have similar affinities for SR95531 (Wafford et al., 2001), but $\delta$-subunit containing receptors have a 50-fold higher affinity for GABA than $\gamma$-subunit-containing receptors (Saxena and Macdonald, 1996). Therefore, because of their different GABA affinities, a nonsaturating concentration of a competitive antagonist with the appropriate properties would more likely prevent GABA binding and thus block $\gamma$-subunit-containing receptors to a greater extent than $\delta$-subunit-containing receptors. The $K_{\text {on }}$ and $K_{\text {off }}$ values for SR95531 are $4.28 \times 10^{7} \mathrm{M}^{-1} \mathrm{sec}^{-1}$ and $9.1 \mathrm{sec}^{-1}$, respectively (Jones et al., 1998), indicating that the binding affinity and off rate are sufficient to differentially affect high- and low-affinity $\mathrm{GABA}_{\mathrm{A}} \mathrm{Rs}$. If tonic inhibition recorded in dentate gyrus granule cells is primarily mediated by $\mathrm{GABA}_{\mathrm{A}}$ Rs with a higher affinity for GABA than receptors mediating phasic inhibition, then there should be a concentration of SR95531 that will barely block tonic inhibition but considerably antagonize phasic inhibition. Furthermore, very high concentrations of this antagonist should outcompete GABA at both receptors and completely block both conductances. We have previously demonstrated these predictions with a kinetic model of tonic and phasic inhibition using a nondesensitizing, high GABA-affinity receptor for tonic inhibi-

This article is published in The Journal of Neuroscience, Rapid Communications Section, which publishes brief, peerreviewed papers online, not in print. Rapid Communications are posted online approximately one month earlier than they would appear if printed. They are listed in the Table of Contents of the next open issue of JNeurosci. Cite this article as: JNeurosci, 2002, 22:RC223 (1-5). The publication date is the date of posting online at www.jneurosci.org.

http://www.jneurosci.org/cgi/content/full/6399 


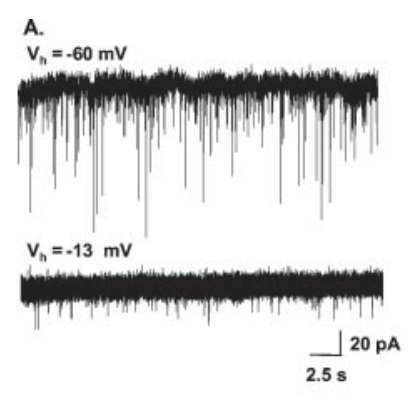

c.

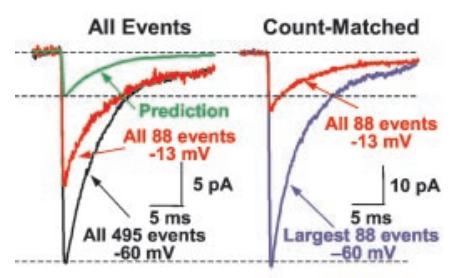

B.

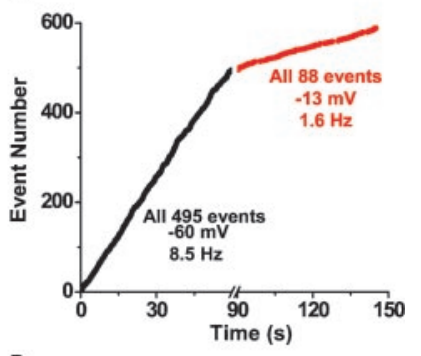

D.

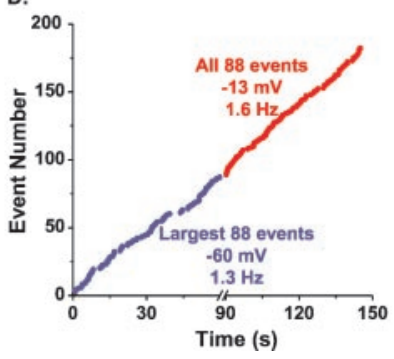

Figure 1. Estimation of the true change in SIPSC amplitudes by largest amplitude count matching. $A$, Sample traces showing reduction in SIPSC amplitude and frequency when $V_{\mathrm{h}}$ is reduced by $79 \%$ from -60 to -13 $\mathrm{mV}$. $B$, Plot of absolute time versus event number for all consecutive sIPSCs shows reduced frequency (average slope) after the change in $V_{\mathrm{h}}$ (red). Thus, most events $(\sim 82 \%)$ recorded at $-60 \mathrm{mV}$ were driven below detection threshold at $-13 \mathrm{mV}$. C, Averages of all sI PSCs before (black; $25.9 \mathrm{pA})$ and after (red; $16.5 \mathrm{pA})$ decreased $V_{\mathrm{h}}$ indicate an apparent decrease of $36 \%$, yet an amplitude reduction of $79 \%$ is predicted by the decreased driving force (green). Because lowering $V_{\mathrm{h}}$ should not change frequency, the fewer events $(n=88)$ recorded during $60 \mathrm{sec}$ at $-13 \mathrm{mV}$ must correspond to the 88 largest amplitude events (of 495 total) recorded during $60 \mathrm{sec}$ at $-60 \mathrm{mV}$. As predicted by the change in driving force, the average at $-13 \mathrm{mV}$ (red; $16.5 \mathrm{pA}$ ) is $27 \%$ of the averaged largest 88 events at $-60 \mathrm{mV}$ (blue; $60.9 \mathrm{pA})$. D, The frequency of the largest 88 events recorded at $-60 \mathrm{mV}$ (blue) is comparable with the frequency of all events recorded at $-13 \mathrm{mV}$ (red).

tion and a desensitizing receptor with 50-fold lower GABA affinity for phasic inhibition (see Materials and Methods). In this model, using the on- and off-rates of SR95531 binding determined experimentally (Jones et al., 1998), 200 nM SR95531 differentially affected tonic and phasic inhibition, whereas $10 \mu \mathrm{M}$ SR95531 abolished them both (Stell and Mody, 2001).

\section{MATERIALS AND METHODS}

Slice preparation and in vitro electrophysiological recordings. Thirty-two 13- to 29-d-old C57Black6 male mice were individually anesthetized with halothane before decapitation. The brains were then removed and placed into an ice-cold artificial CSF (ACSF) containing (in $\mathrm{mM}$ ): $126 \mathrm{NaCl}, 2.5$ $\mathrm{KCl}, 2 \mathrm{CaCl}_{2}, 2 \mathrm{MgCl}_{2}, 1.25 \mathrm{NaH}_{2} \mathrm{PO}_{4}, 26 \mathrm{NaHCO}_{3}, 10$ D-glucose, $\mathrm{pH}=$ 7.3 when bubbled with $95 \% \mathrm{O}_{2}$ and $5 \% \mathrm{CO}_{2}$. Coronal slices $(350 \mu \mathrm{m}$ in thickness) were cut with a Vibratome (Leica VT1000S) and stored at $32^{\circ} \mathrm{C}$ until they were transferred to the recording chamber. During recordings, the slices were perfused continuously with $33-35^{\circ} \mathrm{C}$ ACSF containing 3-5 mm kynurenic acid (Sigma, St. Louis, MO). All recordings were made from the somata of visually identified neurons (Zeiss Axioscope IR-DIC videomicroscopy; 40× water immersion objective) with an Axopatch 200B amplifier (Axon Instruments, Foster City, CA). Intracellular solutions contained (in $\mathrm{mM}$ ): $140 \mathrm{CsCl}, 1 \mathrm{MgCl}_{2}, 10$ HEPES, and 4 Na-ATP. All solutions were titrated to $\mathrm{pH} 7.25$ and an osmolarity of 280-290 mOsm. The DC resistances of the electrodes were 5-8 M $\Omega$ when filled with pipette solution. Series resistance and wholecell capacitance were estimated by compensating for the fast transients evoked at the onset and offset of $8 \mathrm{msec}, 5 \mathrm{mV}$ voltage-command steps. The series resistance was compensated by $70-80 \%$ (with $7-8 \mu \mathrm{sec}$ lag values). Before compensation, series resistance was $<20 \mathrm{M} \Omega$ in dentate granule cells and CA1 pyramidal cells. To identify $\mathrm{GABA}_{\mathrm{A}}$ receptor-

mediated currents, SR95531 (10 mM stock solution; Sigma) was injected directly into the bath, resulting in an estimated saturating bath concentration of SR95531 (100-200 $\mu \mathrm{M})$. The details of how the magnitude of the tonic current was quantified was described previously (Nusser and Mody, 2002). Briefly, we sampled the mean holding current recorded during $5 \mathrm{msec}$ epochs every $100 \mathrm{msec}$ and discarded epochs landing on the decay of any IPSCs, as identified by an increased SD of the $5 \mathrm{msec}$ epoch. Averages of $10 \mathrm{sec}$ samples of the uncontaminated baseline current, recorded $30 \mathrm{sec}$ before (see Fig. 3, BL1) and $30 \mathrm{sec}$ after (see Fig. $3, B L 3)$ a rapid application of $>100 \mu \mathrm{M}$ SR95531, were then compared with another $10 \mathrm{sec}$ sample that ended immediately before the application of $>100 \mu \mathrm{M}$ SR95531 (see Fig. 3, BL2). The difference between samples BL1 and BL2 was attributed to random slow baseline fluctuations, and the difference between BL2 and BL3 was attributed to tonic inhibitory current.

Data analysis. All recordings were low-pass filtered at $3 \mathrm{kHz}$ and digitized on-line at $20 \mathrm{kHz}$. In-house data acquisition and analysis software (written in LabView) were used to detect synaptic currents and measure the amplitudes and frequencies of spontaneous IPSCs (sIPSCs).

Kinetic model. Phasic currents were simulated using Berkeley Madonna (v. 8.0.1) with a seven-state kinetic model (Jones and Westbrook, 1997) and an additional state for the competitive antagonist binding, using a 0.3 msec pulse of GABA (1 mM) in either the presence or absence of $200 \mathrm{nM}$ SR95531. $K_{\mathrm{on}}$ and $K_{\mathrm{off}}$ values of $4.28 \times 10^{7} \mathrm{M}^{-1} \mathrm{sec}^{-1}$ and $9.1 \mathrm{sec}^{-1}$, respectively, were used for SR95531, and values of $5 \times 10^{7} \mathrm{M}^{-1} \mathrm{sec}^{-1}$ and $2.4 \times 10^{3} \mathrm{sec}^{-1}$, respectively, were used for GABA. Tonic currents were simulated with a similar model in which the GABA $K_{\text {off }}$ value was changed to $48 \mathrm{sec}^{-1}$ (a 50-fold increase in affinity), and the desensitized states were removed to simulate a high-affinity nondesensitizing receptor. This latter simulation used a sustained pulse of $1 \mu \mathrm{M}$ GABA to mimic tonic activation. Simulations of the two receptors showed a differential block of tonic and phasic currents by $200 \mathrm{~nm} \mathrm{SR} 95531$ (Stell and Mody, 2001).
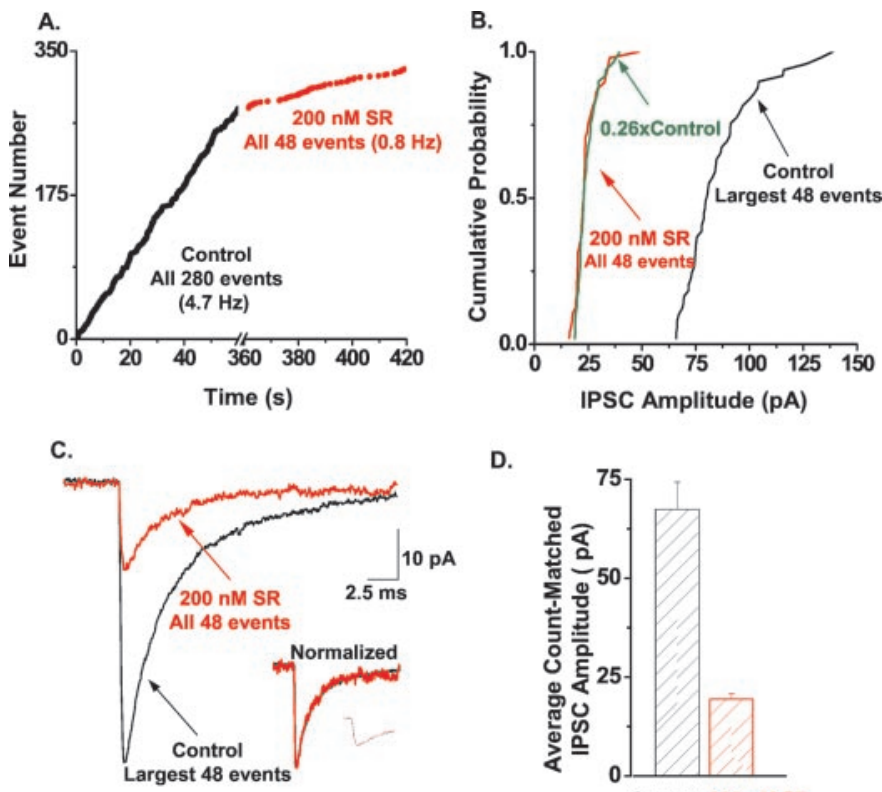

D.

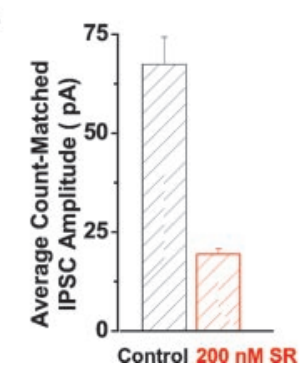

Figure 2. SR95531 (200 nM) reduces sIPSCs without changing their kinetics. $A$, Average slope representing frequency (Control, $4.7 \mathrm{~Hz}$, black; $200 \mathrm{~nm}$ SR95531, $0.8 \mathrm{~Hz}$, red $)$ shows that most events (83\%) are reduced below detection threshold. $B$, A cumulative probability plot demonstrating that the distribution of the largest 48 events recorded under control conditions (black) matches the distribution of events recorded in the presence of $200 \mathrm{~nm}$ SR95531 (red) when scaled down by $74 \%$ (green). $C$, Averages of the largest 48 sIPSCs from one cell under control conditions (black) and all events recorded in $200 \mathrm{nM}$ SR95531 (red) reveals a $74 \%$ block by SR95531 (Control, 83.5 pA; 200 nM SR95531, 21.4 pA). Insets show normalized sIPSCs with similar kinetics before and after drug treatment. $D$, Average sIPSC amplitudes are reduced by $71 \%(n=4)$ in $200 \mathrm{~nm}$ SR95531. SR, SR95531. 


\section{RESULTS}

\section{Quantification of sIPSC reduction}

By lowering the holding potential $\left(V_{\mathrm{h}}\right)$ in dentate gyrus granule cells from $-60 \mathrm{mV}$ to $-13 \mathrm{mV}\left(E_{\mathrm{C} 1}=0 \mathrm{mV}\right)$ and thereby reducing the driving force on $\mathrm{Cl}^{-}$efflux by $79 \%$, we demonstrated how decreases in sIPSC frequency (Fig. $1 A, B$ ) resulting from decreases in sIPSC amplitudes (Fig. $1 A, C$ ) can lead to an inaccurate quantification of average sIPSC amplitudes (Fig. $1 C$ ). On the basis of the linearity of $\mathrm{Cl}^{-}$conductance through GABAgated channels (Bormann et al., 1987), a 79\% decrease in driving force should decrease the average peak sIPSC by $79 \%$ as well. Yet when the average amplitude of all the events in the $60 \mathrm{sec}$ epoch, recorded before $\Delta V_{\mathrm{h}}$ was compared with the average recorded in the epoch after $\Delta V_{\mathrm{h}}$, the average peak sIPSC amplitude was decreased by only $36 \%$ (i.e., less than half of the predicted value) (Fig. 1C). However, when sIPSCs recorded during the reduced driving force were compared only with the same number of the largest events recorded before the change in driving force, the average reduction in peak sIPSC amplitude was comparable with the predicted value (Fig. $1 C$ ), and the average frequency of spontaneous events was similar in the two recordings (Fig. 1D). Thus, matching the count of largest amplitude events before and after any manipulation that lowers the frequency attributable solely to diminished amplitude is a reliable method that can be used to accurately compare real amplitude changes. We therefore used this method to compare amplitude changes of phasic currents recorded before and after application of SR95531.

\section{Effect of 200 nm SR95531 on phasic inhibition}

To determine whether phasic currents are mediated by receptors with lower GABA affinity than receptors mediating tonic currents, we first assessed the effect of $200 \mathrm{nM}$ SR95531 on phasic currents recorded in dentate gyrus granule cells. Bath perfusion of $200 \mathrm{~nm}$ SR95531 reduced the sIPSC frequency by $73 \pm 5.0 \%$ $(n=4)$ (Fig. $2 A$, example from one cell). The decreased frequency was attributed to sIPSC amplitude reduction and not to decreased frequency of released GABA, because similar frequency and amplitude reductions resulted in the presence of $1 \mu \mathrm{M}$ TTX when miniature IPSCs (mIPSCs) were recorded instead of sIPSCs (frequency reduced by $63.2 \pm 7.4 \%$; amplitude reduced by $62.1 \pm 4.0 \% ; n=4)$. When count matching was used to compare the average peak sIPSC amplitude recorded before and after 200 nM SR95531 application, the amplitude was decreased by $71 \pm 1.4 \%(n=4)$ (Fig. $2 C, D)$, and the kinetics remained unaltered (Fig. $2 C$, inset). When the peak amplitude distribution is compared in a cumulative histogram before and after drug application, it is clear that the distribution of the largest events before drug application is scaled down by a constant to match the distribution of events after drug application (Fig. 2B). This further demonstrates that $200 \mathrm{~nm}$ SR95531 directly reduced peak sIPSC amplitude, and only the largest events were of sufficient size to be separated from the background noise after the drug reduced their amplitudes.

\section{Effect of $\mathbf{2 0 0}$ nм SR95531 on tonic inhibition}

Because our model predicted that 200 nm SR95531 should affect tonic inhibition to a lesser extent than phasic inhibition, we next looked at the effect of $200 \mathrm{~nm}$ SR95531 on tonic inhibition recorded in dentate gyrus granule cells. When GABA uptake was blocked by the GABA transporter 1 (GAT-1) inhibitor NO-711 $(10 \mu \mathrm{M})$, a tonic current was revealed in dentate gyrus granule cells as a steady conductance blocked by high concentrations of
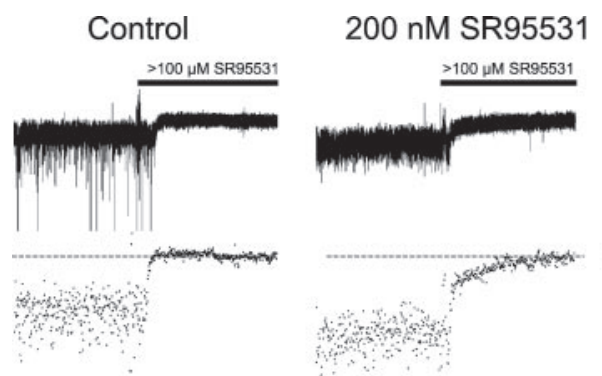

$10 \mu \mathrm{M}$ SR95531
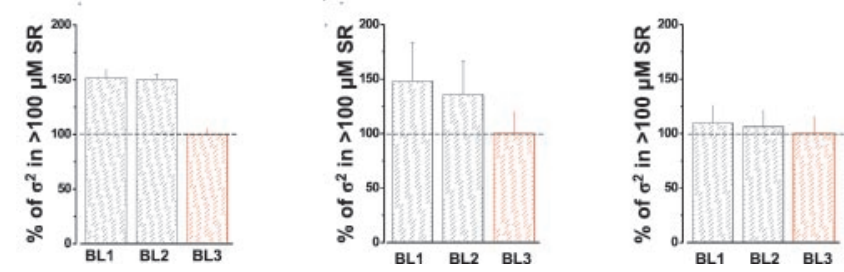

Figure 3. Tonic inhibition is unaffected by $200 \mathrm{~nm}$ SR95531 but is abolished by $10 \mu \mathrm{M}$ SR95531 in dentate gyrus granule cells. Sample traces show the effect of $>100 \mu \mathrm{M}$ SR95531 under control conditions (left) and in the presence of $200 \mathrm{nM}$ (middle) and $10 \mu \mathrm{M}$ (right) SR95531. Note the large reduction of phasic inhibition in $200 \mathrm{nM}$ SR95531 (also see Fig. 2) and the absence of both phasic and tonic inhibitions in $10 \mu \mathrm{M}$ SR95531. Middle panels represent the magnitude of the tonic current (control, 14.4 pA; 200 nM SR95531, 16.8 pA; $10 \mu \mathrm{M} \mathrm{SR95531,} \mathrm{-1.6} \mathrm{mV)} \mathrm{as} \mathrm{measured} \mathrm{by}$ $5 \mathrm{msec}$ baseline epochs uncontaminated by sIPSCs (see Materials and Methods). The effects of SR95531 on baseline variance (bottom panels) are expressed as a percentage of $\mathrm{GABA}_{\mathrm{A}}$ receptor-independent membrane fluctuations recorded after all $\mathrm{GABA}_{\mathrm{A}}$ currents were abolished with $>100 \mu \mathrm{M}$ SR95531; $200 \mathrm{~nm}$ SR95531 does not change baseline variance, whereas $10 \mu \mathrm{M}$ SR95531 reduces baseline variance to levels recorded in $>100 \mu \mathrm{M}$ SR95531. BL1, BL2, and $B L 3$ represent averages of $10 \mathrm{sec}$ of uncontaminated baseline epochs (from middle panels) separated by $30 \mathrm{sec}$. BL2 terminates with the application of $>100 \mu \mathrm{M}$ SR95531, and $B L 3$ (red) represents variances recorded $30 \mathrm{sec}$ after GABA receptordependent variances were removed by $100 \mu \mathrm{M}$ SR95531. SR, SR95531.

SR95531 $(>100 \mu \mathrm{M})$. The average tonic current measured (see Materials and Methods) under control conditions (Fig. 3, example from one cell) was $7.4 \pm 1.1 \mathrm{pA}(n=11)$ and was significantly different from the random slow baseline fluctuations of $1.0 \pm 0.2$ pA $(p<0.05)$. When the same experiment was repeated in the presence of $200 \mathrm{nM}$ SR95531, the phasic IPSCs were nearly abolished, but the tonic current recorded was $8.0 \pm 2.6 \mathrm{pA}(n=$ 9) (Fig. 3, example from one cell), which was significantly different from the random slow baseline fluctuations of $1.8 \pm 0.4 \mathrm{pA}(p<$ $0.05)$ and not significantly different $(p>0.05)$ from the tonic current recorded with no SR95531 present. Furthermore, measurement of the variance in current traces uncontaminated by IPSCs revealed baseline noise sensitive to $>100 \mu \mathrm{M}$ SR95531, indicating that this noise was caused by $\mathrm{GABA}_{\mathrm{A}} \mathrm{R}$ activation. In contrast to the effect of the high antagonist concentration, this noise was unaffected by 200 nм SR95531 (Fig. 3, bottom panels).

\section{Effect of $10 \mu \mathrm{M}$ SR95531 on tonic inhibition in dentate gyrus granule cells}

Because the prediction is that greater concentrations of SR95531 will out-compete GABA at both high- and low-affinity receptors to eliminate currents mediated by both receptors, we next tested the effect of $10 \mu \mathrm{M}$ SR95531 on tonic and phasic currents. As demonstrated in Figure 3, incubation of the slices in the higher concentration of the drug for $\sim 5$ min eliminated both phasic and tonic currents. In the presence of $10 \mu \mathrm{M}$ SR95531, tonic currents $(0.5 \pm 3.6 \mathrm{pA} ; n=4)$ were not significantly different $(p>0.05)$ from the random baseline fluctuations $(2.4 \pm 0.6 \mathrm{pA} ; n=4)$. As 
expected, baseline noise seen in control conditions before the application of $>100 \mu \mathrm{M}$ SR95531 was also eliminated by $10 \mu \mathrm{M}$ SR95531 (Fig. 3, bottom panels).

\section{Effect of $10 \mu \mathrm{M}$ SR95531 on tonic inhibition in CA1 pyramidal cells}

Because there are conflicting reports in the literature, we performed experiments to determine whether $10 \mu \mathrm{M}$ SR95531 also affects tonic currents recorded in CA1 pyramidal cells. We recorded similar results when experiments were performed in CA1: tonic currents recorded under control conditions $(16.0 \pm 5.1 \mathrm{pA}$; $n=6)$ were significantly abolished $(p>0.05)$ by $10 \mu \mathrm{M}$ SR95531 $(2.0 \pm 0.3 \mathrm{pA} ; n=3)$. Our results are consistent with previous findings by Overstreet and Westbrook (2001) showing that $5 \mu \mathrm{M}$ SR95531 blocks tonic currents when they are revealed by the GABA transaminase inhibitor $\gamma$-vinyl-GABA (GVG) or the combination of GVG and the GAT-1 GABA transport blocker NO711. However, our results are in disagreement with the results of Bai et al. (2001), which indicate that $20 \mu \mathrm{M}$ SR95531 does not affect tonic currents and inhibits only phasic currents.

\section{DISCUSSION}

\section{Largest amplitude event count matching}

On the basis of the predictions of our kinetic modeling (Stell and Mody, 2001) we recorded the effects of two different concentrations of SR95531 on tonic and phasic inhibitions to test the hypothesis that they are mediated by $\mathrm{GABA}_{\mathrm{A}}$ Rs with high and low GABA affinities, respectively. However, when quantifying the effect of the antagonist on phasic currents, we found that reduction of sIPSC amplitude resulted in reduction of SIPSC frequency and led to inaccuracies in the quantification of the average decrease in phasic current amplitude. This reduction in frequency was a consequence of reducing the size of the smallest events by the competitive antagonist beyond the detection capabilities (i.e., rendering them indistinguishable from the membrane noise of whole-cell recordings), and therefore a method for quantifying the unbiased reduction of event amplitude was necessary.

After reducing the postsynaptic driving force for $\mathrm{Cl}^{-}$(a manipulation that should not affect presynaptic GABA release), any changes in event frequency had to result from the decreased event amplitude. Thus, events recorded with the lowered driving force should correspond to a similar number of the largest amplitude events (recorded during the same amount of time) under control conditions, and the average of only these latter events should be compared with the average of the partially antagonized responses. The average amplitude decrease was commensurate with the lower GABA current predicted by the change in driving force, demonstrating that largest-event count matching is an accurate determination of changes in sIPSC amplitude when IPSC amplitude changes affect detected sIPSC frequency.

When the effect of SR95531 on phasic inhibition was quantified, experiments yielded similar results in the presence or absence of TTX, indicating that event frequency was reduced as a result of reduced sIPSC amplitude and not caused by any presynaptic effects of the antagonist. This result ensured that a potential reduction of GABAergic drive onto inhibitory neurons by SR95531 (200 nM) in the absence of TTX did not lead to an increased frequency of action potential-driven IPSCs recorded in principal cells. Therefore, reductions in sIPSC frequency could be unequivocally attributed to the effect of the antagonist at postsynaptic $\mathrm{GABA}_{\mathrm{A}}$ Rs. Accordingly, the method of largest am- plitude count matching could be used to quantify sIPSC amplitude reduction caused by the antagonist.

With this method we were able to produce the first quantitative determination of changes in hippocampal spontaneous inhibitory activity caused by a competitive $\mathrm{GABA}_{\mathrm{A}} \mathrm{R}$ antagonist. Epileptiform activity is highly dependent on GABAergic inhibition (Treiman, 2001), and it has been reported that inhibitory deficits of only $10-20 \%$ can greatly influence its generation and propagation throughout the brain (Tribble et al., 1983; Chagnac-Amitai and Connors, 1989). In these studies, however, quantification of the $10-20 \%$ inhibitory deficit has been based on the assumption that inhibition is uniformly reduced throughout the brain by low concentrations of competitive antagonist (Chagnac-Amitai and Connors, 1989) or on the effects of competitive antagonists in other regions of the nervous system without any precise values for deficits in total inhibitory activity (Gallagher et al., 1978; Tribble et al., 1983; Yakushiji et al., 1987). It is clear that slight inhibitory reductions can affect the generation and propagation of epileptiform activity in the neocortex (Chagnac-Amitai and Connors, 1989), and therefore a method of precise quantification of these reductions is essential for understanding the influence of GABAergic mechanisms on epileptiform activity. In our study, the $71 \%$ reduction in phasic inhibition produced by $200 \mathrm{~nm}$ SR95531 also caused spontaneous epileptiform field potentials in the CA3 region (our unpublished observations), opening the possibility of determining the precise relationship between inhibitory deficiency and hyperexcitability.

\section{Tonic and phasic receptor affinity differences}

We demonstrate that with 200 nM SR95531 tonic inhibition can be pharmacologically separated from phasic inhibition, whereas 10 $\mu \mathrm{M}$ SR95531 completely blocks both of these inhibitory conductances. This effect is consistent with receptors that mediate tonic inhibition having a higher affinity for GABA than the receptors that mediate phasic inhibition, while they have similar affinities for SR95531. Although our results can also be explained if the receptors mediating the two currents have different affinities for the antagonist, we favor the first explanation because it is consistent with the following observations from several other labs. Clearly, GABA ${ }_{\mathrm{A}}$ Rs have very different properties depending on their subunit composition (Hevers and Luddens, 1998). Receptors expressing $\delta$-subunits with affinities for GABA 50-fold higher than receptors lacking $\delta$-subunits (Saxena and Macdonald, 1996) show similar affinity for SR95531 to receptors lacking $\delta$-subunits (Wafford et al., 2001). In the cerebellum, high-affinity $\mathrm{GABA}_{\mathrm{A}} \mathrm{Rs}$ containing $\delta$-subunits are located exclusively extrasynaptically (Nusser et al., 1998), and they show little desensitization to a sustained presentation of GABA (Saxena and Macdonald, 1994). A similar arrangement in the hippocampus would be ideal for sensing the sustained low concentrations of GABA (Lerma et al., 1986; Tossman et al., 1986). Because $\delta$-subunits are highly expressed in the dentate gyrus (Sperk et al., 1997), receptors expressing these subunits may also be extrasynaptic and may be responsible for generating the tonic inhibition found in dentate gyrus granule cells. Because of their high affinity for GABA, these receptors would be able to sense low ambient GABA concentrations and would function after phasic currents are blocked by competitive antagonists. Future studies will have to establish the precise identity and anatomical localization of the receptors responsible for mediating the tonic conductance in dentate gyrus granule cells. Thus, in addition to the pharmacological enhancements of the two types of inhibition previously 
demonstrated (Nusser and Mody, 2002), we have now demonstrated a means for specifically reducing phasic inhibition.

\section{REFERENCES}

Araujo F, Ruano D, Vitorica J (1998) Absence of association between delta and gamma2 subunits in native $\operatorname{GABA}(\mathrm{A})$ receptors from rat brain. Eur J Pharmacol 347:347-353.

Bai D, Zhu G, Pennefather P, Jackson MF, MacDonald JF, Orser BA (2001) Distinct functional and pharmacological properties of tonic and quantal inhibitory postsynaptic currents mediated by gammaaminobutyric acid(A) receptors in hippocampal neurons. Mol Pharmacol 59:814-824.

Bormann J, Hamill OP, Sakmann B (1987) Mechanism of anion permeation through channels gated by glycine and gamma-aminobutyric acid in mouse cultured spinal neurones. J Physiol (Lond) 385:243-286.

Brickley SG, Cull-Candy SG, Farrant M (1996) Development of a tonic form of synaptic inhibition in rat cerebellar granule cells resulting from persistent activation of GABAA receptors. J Physiol (Lond) 497:753-759.

Brickley SG, Cull-Candy SG, Farrant M (1999) Single-channel properties of synaptic and extrasynaptic $\mathrm{GABA}_{\mathrm{A}}$ receptors suggest differential targeting of receptor subtypes. J Neurosci 19:2960-2973.

Brickley SG, Revilla V, Cull-Candy SG, Wisden W, Farrant M (2001) Adaptive regulation of neuronal excitability by a voltage-independent potassium conductance. Nature 409:88-92.

Chagnac-Amitai Y, Connors BW (1989) Horizontal spread of synchronized activity in neocortex and its control by GABA-mediated inhibition. J Neurophysiol 61:747-758.

Essrich C, Lorez M, Benson JA, Fritschy JM, Luscher B (1998) Postsynaptic clustering of major GABAA receptor subtypes requires the gamma 2 subunit and gephyrin. Nat Neurosci 1:563-571.

Gallagher JP, Higashi H, Nishi S (1978) Characterization and ionic basis of GABA-induced depolarizations recorded in vitro from cat primary afferent neurones. J Physiol (Lond) 275:263-282.

Hevers W, Luddens H (1998) The diversity of GABAA receptors. Pharmacological and electrophysiological properties of GABAA channel subtypes. Mol Neurobiol 18:35-86.

Jones MV, Westbrook GL (1997) Shaping of IPSCs by endogenous calcineurin activity. J Neurosci 17:7626-7633.

Jones MV, Sahara Y, Dzubay JA, Westbrook GL (1998) Defining affinity with the $\mathrm{GABA}_{\mathrm{A}}$ receptor. J Neurosci 18:8590-8604.

Jones MV, Jonas P, Sahara Y, Westbrook GL (2001) Microscopic kinet- ics and energetics distinguish $\mathrm{GABA}(\mathrm{A})$ receptor agonists from antagonists. Biophys J 81:2660-2670.

Lerma J, Herranz AS, Herreras O, Abraira V, Martin R (1986) In vivo determination of extracellular concentration of amino acids in the rat hippocampus. A method based on brain dialysis and computerized analysis. Brain Res 384:145-155.

Mody I (2001) Distinguishing between GABA(A) receptors responsible for tonic and phasic conductances. Neurochem Res 26:907-913.

Nusser Z, Mody I (2002) Selective modulation of tonic and phasic inhibitions in dentate gyrus granule cells. J Neurophysiol, in press.

Nusser Z, Sieghart W, Somogyi P (1998) Segregation of different $\mathrm{GABA}_{\mathrm{A}}$ receptors to synaptic and extrasynaptic membranes of cerebellar granule cells. J Neurosci 18:1693-1703.

Overstreet LS, Westbrook GL (2001) Paradoxical reduction of synaptic inhibition by vigabatrin. J Neurophysiol 86:596-603.

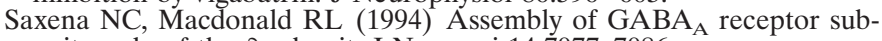
units: role of the $\delta$ subunit. J Neurosci 14:7077-7086.

Saxena NC, Macdonald RL (1996) Properties of putative cerebellar gamma-aminobutyric acid A receptor isoforms. Mol Pharmacol 49:567-579.

Somogyi P, Fritschy JM, Benke D, Roberts JD, Sieghart W (1996) The gamma 2 subunit of the GABAA receptor is concentrated in synaptic junctions containing the alpha 1 and beta $2 / 3$ subunits in hippocampus, cerebellum and globus pallidus. Neuropharmacology 35:1425-1444.

Sperk G, Schwarzer C, Tsunashima K, Fuchs K, Sieghart W (1997) $\mathrm{GABA}(\mathrm{A})$ receptor subunits in the rat hippocampus. I: Immunocytochemical distribution of 13 subunits. Neuroscience 80:987-1000.

Stell BM, Mody I (2001) Phasic and tonic GABA conductances in the hippocampus are mediated by receptors with different affinities. Soc Neurosci Abstr 27:503.2.

Tossman U, Jonsson G, Ungerstedt U (1986) Regional distribution and extracellular levels of amino acids in rat central nervous system. Acta Physiol Scand 127:533-545.

Treiman DM (2001) GABAergic mechanisms in epilepsy. Epilepsia 42 [Suppl 3]:8-12.

Tribble GL, Schwindt PC, Crill WE (1983) Reduction of postsynaptic inhibition tolerated before seizure initiation: brain stem. Exp Neurol $80: 304-320$

Wafford KA, Brown N, Kerby J, Bonnert TP, Whiting PJ (2001) Pharmacology of the novel human $\alpha 4$, [beta 3], $\delta$, GABA receptor subtype. Soc Neurosci Abstr 27:35.4

Yakushiji T, Tokutomi N, Akaike N, Carpenter DO (1987) Antagonists of GABA responses, studied using internally perfused frog dorsal root ganglion neurons. Neuroscience 22:1123-1133. 